\title{
Ethics perception: evidence from accountants and accounting students in Brazil
}

Percepção ética: evidência de contadores e estudantes de contabilidade no Brasil

\section{Percepción ética: evidencia de contables y estudiantes de contabilidad en Brasil}

Perception éthique: temoignages de comptables et d'étudiants en comptabilité au Brésil

\author{
Jessica de Morais Lima ${ }^{1}$ \\ Marcia Maria dos Santos Bortolocci Espejo² \\ Marcelo Botelho da Costa Moraes ${ }^{1}$ \\ Emanoel Marcos Lima²
} http://dx.doi.org/10.20435/inter.v20i2.1888

\begin{abstract}
Due to the new international ethics standards law, knowing what Brazilian accountants and accounting students perceive as ethical is extremely important. An online survey with 29 questions was conducted in MS/Brazil with different scenarios, involving different aspects that may influence someone's decision, to assess the acceptance of unethical behaviors. The results showed difference in the ethics perception by students and accountants, but the difference was greater based on gender.

Keywords: ethics code; accountants' ethics; ethics perception; Brazil.

Resumo: Devido à nova lei internacional de padrões éticos, saber o que os contadores e estudantes de contabilidade percebem como ético é de extrema importância. Uma pesquisa online com 29 questões foi conduzida no MS/Brasil com diferentes cenários, envolvendo diferentes aspectos que podem influenciar a decisão de alguém, para avaliar a aceitação de comportamentos antiéticos. Os resultados mostraram diferenças entre a percepção ética dos estudantes e contadores, mas a diferença foi maior baseada no gênero. Palavras-chave: código de ética; ética do contador; percepção ética; Brasil.

Resumen: Debido a la nueva ley internacional de estándares éticos, saber lo que los contadores y estudiantes de contabilidad perciben como ético es muy importante. Una encuesta en línea con 29 preguntas fue conducida en MS/Brasil con diferentes escenarios, involucrando diferentes aspectos que pueden influir en la decisión de alguien, para evaluar la aceptación de comportamientos antiéticos. Los resultados mostraron diferencias entre la percepción ética de los estudiantes y los contadores, pero la diferencia fue mayor basada en el género.
\end{abstract}

Palabras claves: código de ética; ética del contador; percepción ética; Brasil.

Résumé: En raison de la nouvelle loi internationale sur les normes éthiques, il est important de savoir ce que les comptables et étudiants en comptabilité perçoivent comme éthique.Un sondage en ligne de 29 questions a été mené dans de MS/Brésil. À travers différent scénarios comprenant différents aspects pouvant influencer la décision d'une personne,le sondage évalue l'acceptation de comportements contraires à l'éthique. Les résultats indiquent des différences de perception éthique entre étudiants et comptables, mais la différence est d'avantage marquée selon le sexe du répondant.

Mots-clés: code d'éthique; ethique comptable; perception éthique; Brésil.

\section{INTRODUCTION}

There are no human group that does not oblige to a moral code even if what is perceived as normal to one group can be considered as the door to hell to another (SROUR, 1994). The historical evolution of ethics dates back to ancient Greek, however the lack of records does not prevent that the cave man for example, had a code of conduct. Gilles (1994) reports that over

\footnotetext{
${ }^{1}$ Faculdade de Economia, Administração e Contabilidade de Ribeirão Preto (USP), Ribeirão Preto, São Paulo, Brasil.

${ }^{2}$ Universidade Federal do Mato Grosso do Sul (UFMS), Campo Grande, Mato Grosso do Sul, Brasil.
} 
two thousand years ago, Christianity already tried to introduce values and moral principles to the human kind.

Each human has a specific behavior usually guided by what is acceptable by the group. Sá (2001) stated that most of the time the group decision is for self-defense creating different ethical behaviors throughout. All the differences can generate conflicts when there is interaction between groups and since the globalization made the relations between countries more active, the debate about ethical practices is even more relevant.

Specifically, since the adoption of the International Financial Reporting Standards the accounting profession has become more important in the business world and with so, the understanding of accountants' proper ethical behavior is not only needed but necessary. Antonovz, Stanley and Espejo (2016) noted that in the many recent accounting scandals the lack of ethical behavior and corporate governance failures have been crucial in the process.

The scandals involving Enron, WorldCom and Quest have contributed to the creation of the Sarbanes-Oxley Act (2002) in the USA. Called by SOX, the new act requires senior executives to establish and follow a Code of Corporate Conduct and ethics policies. These requirements affect any company that intends to public trade in the American Market. Despite all the evidence of how crucial the accountants' ethics is, not all countries require compliance with the code of ethics. Brazil is one of these countries.

Brazil had major recent scandals with Petrobras, the country's oil company. Many politicians involved, many arrests, and a national embarrassment to all finally led Brazil to realize that something had to be done. In 2017 Brazil should have implemented the NOCLAR, non-compliance with laws and regulations, along many other countries. This project should change the standards for Accountants Ethics' Code and make it mandatory for all the companies. However, due to the necessity to change the Brazilian law and regulations to fully commit, Brazil is not yet in conformance with the NOCLAR. On this topic, at the International Federation of Accountants' (IFAC) meeting held in New York on February $28^{\text {th }}, 2018$, the Brazilian Federal Accounting Council's (CFC) technical vice-president Idésio Coelho assured that the efforts to regulate and adapt to the new standards are being made (CFC Brazil, 2018).

Since the scenario is changing the understanding of the ethics perception of the accountants is necessary. This is the primary issue for this empirical study: What is the ethics perception for accountants and accounting students. The main objective of this paper is to analyze if there is a difference between what students are learning to be ethical and what accountants' practice in the organizations as being ethic.

For the future, it is critical to know what constitute the Brazilian accountant's ethics standards.

This paper is presented as follows: (1) literature review, (2) methodology with the sample and techniques used (3) analyses and results of the data collected and (4) conclusion with the limitations of this study.

\section{LITERATURE REVIEW}

\subsection{Ethics and moral}

Ethics and moral are often mistaken to be the same thing, Alves (2005) explain that even though the concepts are similar when it comes to behavior they differentiate when ethics is perceived as science and moral is a rule of conduct. Santos (1959) also articulate that despite the 
similarities they are distinguished in their understanding being that the moral can be understood as the behaviors established by men and ethics dedicates to the study of the rules.

\subsection{Accountants Ethics Code}

Some authors express the Professional Ethics Code as the standard behavior conduct with specifications of each profession (ALVES et al., 2007; SÁ, 2001; LISBOA, 1996). Sá (2001) complements saying that one profession should follow the same order to allow growth of the collective and not the individual. With so, the Ethics Code is used as a guideline with principles known and acceptable by society, more specifically, for the accountants these guidelines are used to maintain the professional image, the duties and responsibilities with society and the profession, and loyalty with the clients (LISBOA, 1996).

\subsection{Brazilian law}

Carrança (2016) interviewed the president of the Institute of Independent Auditors in Brazil $\left(\mathrm{Ibracon}^{3}\right)$, at the time Idésio Coelho, about the new international law of non-compliance with laws and regulations also known as NOCLAR, and according to him the law was still being translated to Portuguese, but it should bring more responsibility to those preparing the financial reports. However, Coelho also reported that some details must be sorted out before the implementation of the new law in Brazil, such as which authority should the professionals report to, something that the original law does not detail.

This project develops new standards for the Accountants Code of Ethics and all the accountants should consider its implications. Brazil should have fully adopted the new law, by July of 2017 and even though it is not mandatory yet, the CFC is working alongside the Legislative to change the laws and regulate this as soon as possible (CFC Brazil, 2018).

The current tax law in Brazil already states that any suspicious activity in the company should be reported by the independent auditors but with the new law, the company's accountants and the independent auditors are obligated to report to the authorities any findings that deviate from the law or regulations such as money laundry, tax avoidance and corruption (CARRANÇA, 2016).

Still in Carrança's interview (2016) Coelho points it out that the new law is more challenging to the company's accountants since the recommendation for the independent auditors is to terminate the contract as soon as the irregularity is identified and for the company's accountant this could mean being forced to resign. The NOCLAR suggests the accountant should report the irregularities to the superiors and if not resolved internally it is mandatory to report to the authorities. Nonetheless, Coelho said that this subject is still in debate with the Brazilian Accounting Federal Board.

\subsection{Influential factors in the decision-making process}

According to Sá (2001) some individuals' characteristics can be influenced by some factors and many are inherent to everyone making a difference in the behavior. Some factors are individuals such as genre, age, nationality, personality, attitude, values, education, profession

\footnotetext{
${ }^{3}$ Brazilian regulator for independent auditors.
} 
and religion. Previous studies do not all agree that all these factors can influence in the ethical perception, e.g. Gilligan (1982) and Biaggio (1999) attested that women are more ethical than men, and this hypothesis was proven by following studies such as Adkins and Radtke (2004), Emerson, Stanley and Conroy (2007). However, some studies disagree with such hypothesis (ABDOLMOHAMMADI; READ; SCARBROUGH, 2003; LOE; FERRELL; MANSFIELD, 2000) and did not find significant differences between women and men's perception of ethics.

Despite any arguments, the character of each individual is what each accepts as good behavior and the acceptance of each behavior can be influenced by many factors, however, the human nature is the first source of ethics (LISBOA, 1996). The other sources of ethics listed by Lisboa (1996) is the environment, the consideration of human behavior, the country's culture and particular behaviors, as shown on Table 1.

Table 1 - Ethics Source

\begin{tabular}{|l|l|}
\hline \multicolumn{1}{|c|}{ Origin } & \multicolumn{1}{c|}{ Source } \\
\hline Human Nature & Correct character of man \\
\hline Standards of character & Standards of the involved agents \\
\hline $\begin{array}{l}\text { Consequences of reflecting human behavior } \\
\text { principles }\end{array}$ & $\begin{array}{l}\text { Each meaning of ethics becomes the object of } \\
\text { societies' reflection }\end{array}$ \\
\hline Country Laws & Distinct laws for each country \\
\hline Behaviors & Irrational accessible to reason's appeal. \\
\hline
\end{tabular}

Source: Adapted from Lisboa (1996).

\section{METHODOLOGY}

With the already mentioned objective in mind, the hypotheses were developed as follow.

$\mathrm{H}_{0}$ - There is a difference in the ethics perception between accounting students and accountants.

$\mathrm{H}_{1}$ - There is a difference in the ethics perception among men and women.

The online survey leaves room for the self-selection since the receptor can decide to answer the questionnaire or not. With so, the accounting students and the accountants both faced the same ethical situations developed in the questionnaire to assess their ethical attitudes perceptions. Each scenario considers different aspects that may influence someone's decision such as environmental, financial, competition, social and health risks, bribery, cultural and information. There were 28 questions in the Acceptance Questionnaire and it was available in the website for a month in the state of Mato Grosso do Sul. The questions were adapted from the original study performed in the USA by Emerson, Stanley and Conroy (2007).

The first three questions were regarding demographics providing information on age and gender. Following Emerson, Stanley and Conroy (2007) model, the next twenty-five questions were ranked by the respondents using a 07-point Likert-type scale, which range from 01, never acceptable, to 07, always acceptable. On Table 2 we can see which constructs and variables were used in each scenario and the supporting research. 
Table 2 - Research variables in the questionnaire

\begin{tabular}{|c|c|c|c|c|}
\hline & Construct & Variables & Scenario & Authors \\
\hline \multirow{7}{*}{$\begin{array}{c}\text { Ethics } \\
\text { Perception }\end{array}$} & Competition & $\begin{array}{l}\text { Pressure; Search for results; Unfair } \\
\text { competition; Hiring managers or } \\
\text { specialists from competitors to } \\
\text { obtain information on ongoing } \\
\text { projects; Altering weight or } \\
\text { measurements of produced goods. }\end{array}$ & $C, F$ and $Q$ & $\begin{array}{l}\text { Ferrell, Fraedrich and } \\
\text { Ferrell (2001); Srour } \\
\qquad(2003)\end{array}$ \\
\hline & Environmental & $\begin{array}{l}\text { Relation to the environment: final } \\
\text { residue disposition, pollution, water } \\
\text { and energy usage, consumption of } \\
\text { natural resources. }\end{array}$ & $B, R$ and $Y$ & $\begin{array}{l}\text { Moreira (1999); Ferrell, } \\
\text { Fraedrich and Ferrell } \\
\text { (2001) }\end{array}$ \\
\hline & Financial & $\begin{array}{c}\text { Fiscal evasion; Safety and usage } \\
\text { of classified information; Piracy, } \\
\text { software violation; Lying or omissions } \\
\text { policies. }\end{array}$ & $\begin{array}{c}D, I A, P \text { and } \\
W\end{array}$ & $\begin{array}{l}\text { Arruda, Whitaker and } \\
\text { Ramos (2001); Srour } \\
\text { (2003); Sayeg (2003) }\end{array}$ \\
\hline & $\begin{array}{l}\text { Social and } \\
\text { Health risks }\end{array}$ & $\begin{array}{l}\text { Lying or omissions policies that might } \\
\text { cause health risks; adulteration of } \\
\text { weight or measurement of produced } \\
\text { goods; product liability. }\end{array}$ & $L, O, S$ and $X$ & $\begin{array}{l}\text { Moreira (1999); Arruda, } \\
\text { Whitaker and Ramos } \\
\text { (2001) }\end{array}$ \\
\hline & Informational & $\begin{array}{l}\text { Transparency of balance sheet, } \\
\text { financial reports, and board reports } \\
\text { directed to shareholders, accounting } \\
\text { practices; deceitful advertisement. }\end{array}$ & $\mathrm{K}$ and $\mathrm{N}$ & $\begin{array}{l}\text { Moreira (1999); Leal } \\
\text { (2002); Srour (2003); } \\
\quad \text { Srour (2005) }\end{array}$ \\
\hline & Bribes & $\begin{array}{l}\text { Collusion, bribe, paying off biddings, } \\
\text { exportation, oversights or lawsuits; } \\
\text { Acceptance of gifts, gratification, } \\
\text { favors, invitations of suppliers or } \\
\text { customers. }\end{array}$ & $\begin{array}{c}E, G, H, U \\
\text { and } V\end{array}$ & $\begin{array}{l}\text { Moreira (1999); Ferrell, } \\
\text { Fraedrich and Ferrell } \\
\text { (2001); Arruda, Whitaker } \\
\text { and Ramos (2001); } \\
\text { Powpaka (2002); Srour } \\
\text { (2003) }\end{array}$ \\
\hline & Cultural & $\begin{array}{l}\text { Nepotism, favoritism, protection; } \\
\text { Recruitment diversity: women, } \\
\text { disabled, ex-prisoners, black, elderly, } \\
\text { youth and poor people. }\end{array}$ & $\mathrm{J}$ and $\mathrm{M}$ & $\begin{array}{c}\text { Srour (1994); Srour } \\
\text { (2000); Arruda, Whitaker } \\
\text { and Ramos (2001); Daft } \\
\text { (2002); Souza, Pereira } \\
\text { and Maffei (2004); } \\
\text { Machado (2005); Matos } \\
\text { (2008); }\end{array}$ \\
\hline $\begin{array}{l}\text { Individual } \\
\text { Profile }\end{array}$ & $\begin{array}{l}\text { Personal } \\
\text { attributes } \\
\text { connected to } \\
\text { the decision- } \\
\text { making process }\end{array}$ & Age and gender & & $\begin{array}{c}\text { Borkowski and Ugras } \\
\text { (1992); Adkins and } \\
\text { Radtke (2004); Emerson, } \\
\text { Stanley and Conroy } \\
\text { (2007) }\end{array}$ \\
\hline
\end{tabular}

Source: Adapted from Antonovz (2010).

The data collected was analyzed trough the Stata 14.0 software with different techniques such as descriptive analysis, mean and standard deviation, factor analysis, Cronbach's Alpha to validate. For the comparison and the test of the hypothesis between the students and accountants the data was complied with the Cluster analysis and the One-Way ANOVA. 


\section{RESULTS AND DISCUSSION}

After the sample collection of 124 valid questionnaires responded by accounting students and accountants the sample was characterized by 61 students and 63 accountants, $45.2 \%$ were female and $54.8 \%$ male and the age gap between 23 and 30 years old was more representative with $33.9 \%$. All of which can be seen in the charts below.

Graphic 1 - Sample's characteristics

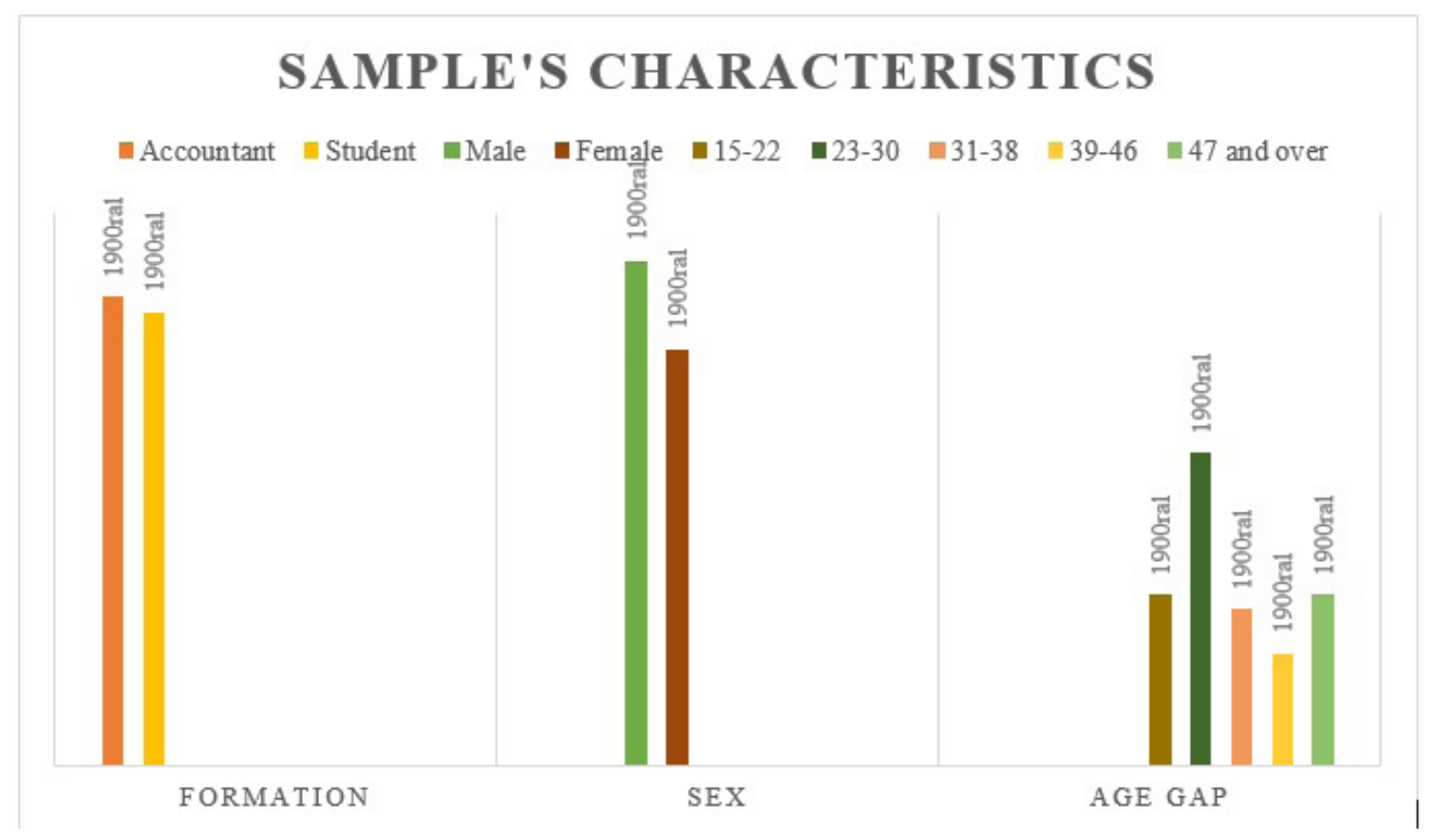

Source: Elaborated by the authors.

Analyzing the mean of the sample in this research it was possible to identify which questions were perceived as more or less acceptable by the individuals. The results can be seen in Table 3 .

Table 3 - Overall summary of descriptive statistcs

\begin{tabular}{|c|c|c|c|}
\hline Variable & N. Obs. & Mean & Std. Dev. \\
\hline Accountant/Student & 124 & .5080645 & .5019631 \\
\hline Sex & 124 & .4516129 & .4996721 \\
\hline Age Gap & 124 & 2.782258 & 1.382589 \\
\hline A & 124 & 2.282258 & 1.783212 \\
\hline B & 124 & 1.516129 & 1.290893 \\
\hline C & 124 & 1.612903 & 1.254 \\
\hline D & 124 & 1.927419 & 1.588441 \\
\hline E & 124 & 2.217742 & 1.850337 \\
\hline F & 124 & 2.459677 & 1.871477 \\
\hline G & 124 & 2.379032 & 1.823927 \\
\hline H & 124 & 2.282258 & 1.787765 \\
\hline I & 124 & 2.169355 & 1.80659 \\
\hline J & 124 & 2.66129 & 1.958459 \\
\hline K & 124 & 2.580645 & 2.099542 \\
\hline
\end{tabular}




\begin{tabular}{|c|c|c|c|}
\hline Variable & N. Obs. & Mean & Std. Dev. \\
\hline L & 124 & 1.629032 & 1.456512 \\
\hline M & 124 & 2.112903 & 1.790715 \\
\hline N & 124 & 2.33871 & 1.84297 \\
\hline O & 124 & 1.629032 & 1.439669 \\
\hline P & 124 & 2.758065 & 1.922782 \\
\hline Q & 124 & 1.387097 & 1.234396 \\
\hline R & 124 & 3.169355 & 2.105825 \\
\hline S & 124 & 2.112903 & 1.786169 \\
\hline T & 124 & 4.112903 & 2.245898 \\
\hline U & 124 & 2.080645 & 1.704116 \\
\hline V & 124 & 2.056452 & 1.649353 \\
\hline$X$ & 124 & 2.717742 & 1.906602 \\
\hline Y & 124 & 1.5 & 1.4511 \\
\hline$Z$ & 124 & 2.193548 & 1.732883 \\
\hline
\end{tabular}

Source: Elaborated by the authors.

With the selected group, the most acceptable situation was scenario $T$, donate obsolete computers, with a mean of 4.11. These findings are similar with the original study by Emerson, Stanley and Conroy (2007) and with the previous study made in the south of Brazil by Antonovz, Stanley and Espejo (2016) where both had the T situation with above 04 results. Also, the least acceptable situation, scenario $B$, exceeding legal limits of pollution and scenario $Q$, rolling back car's odometers to increase sales, had comparable results with the literature.

The answers were submitted to a factorial analysis to group the dimensions with similar characteristics into factors. To verify if there is a significant correlation it was performed the Bartlett Sphericity test with the significance below 0.05 , meaning that there is a positive correlation between the variables. Also, the adequacy was tested with the Kaiser-Meyer-Olkin (KMO) and with a result of 0.849 considered a good result and validating the adequacy of the sample to the factor analysis. Moreover, it was performed the Alpha's Cronbach which is a measurement o reliability that varies from 0 to 1 and the values of 0.6 to 0.7 being the inferior limit of acceptance. The result was of 0.9333 representing that the analysis is acceptable.

Emerson, Stanley and Conroy (2007) originally categorized the scenarios as: (1) legal, even though it might be ethically questionable it is still legal by law; (2) illegal, there is a clear violation of the law; (3) and one question that is ambiguous. The author also categorized the possible results of the actions taken in the stories as being physical or financial harmful. In Table 4 the answers collected are available by category and by groups for the comparison.

Table 4 - Summary statistics by category and group

\begin{tabular}{|c|c|c|c|c|c|c|c|c|}
\hline \multirow{2}{*}{ Scenario } & \multicolumn{2}{|c|}{ Categories } & \multicolumn{3}{c|}{ Student Sample } & \multicolumn{3}{c|}{ Accountants Sample } \\
\cline { 2 - 10 } & Legality & Harm & Mean & Std. Dev. & Obs. & Mean & Std. Dev. & Obs. \\
\hline A & Illegal & Financial & 2.04918 & 1.575079 & 61 & 2.507937 & 1.949963 & 63 \\
\hline B & Illegal & Physical & 1.57377 & 1.146866 & 61 & 1.460317 & 1.423596 & 63 \\
\hline C & Legal & Financial & 1.540984 & .9411654 & 61 & 1.68254 & 1.50081 & 63 \\
\hline D & Illegal & Financial & 1.622951 & 1.293109 & 61 & 2.222222 & 1.791057 & 63 \\
\hline E & Illegal & Financial & 2.344262 & 1.887549 & 61 & 2.095238 & 1.820265 & 63 \\
\hline
\end{tabular}




\begin{tabular}{|c|c|c|c|c|c|c|c|c|}
\hline \multirow{2}{*}{ Scenario } & \multicolumn{2}{|c|}{ Categories } & \multicolumn{3}{c|}{ Student Sample } & \multicolumn{3}{c|}{ Accountants Sample } \\
\cline { 2 - 9 } & Legality & Harm & Mean & Std. Dev. & Obs. & Mean & Std. Dev. & Obs. \\
\hline F & Legal & Financial & 2.52459 & 1.885087 & 61 & 2.396825 & 1.871171 & 63 \\
\hline G & Illegal & Financial & 2.311475 & 1.746816 & 61 & 2.444444 & 1.907352 & 63 \\
\hline H & Legal & Financial & 2.081967 & 1.563064 & 61 & 2.47619 & 1.974492 & 63 \\
\hline I & Illegal & Financial & 2.278689 & 1.808601 & 61 & 2.063492 & 1.812795 & 63 \\
\hline J & Legal & Financial & 2.688525 & 2.03749 & 61 & 2.634921 & 1.894828 & 63 \\
\hline K & Legal & & 2.704918 & 2.201093 & 61 & 2.460317 & 2.006645 & 63 \\
\hline L & Legal & Physical & 1.459016 & 1.162953 & 61 & 1.793651 & 1.686366 & 63 \\
\hline M & Illegal & Financial & 1.836066 & 1.593532 & 61 & 2.380952 & 1.937978 & 63 \\
\hline N & Illegal & Financial & 2.311475 & 1.775209 & 61 & 2.365079 & 1.920195 & 63 \\
\hline O & Ambiguous & Physical & 1.57377 & 1.296907 & 61 & 1.68254 & 1.574242 & 63 \\
\hline P & Illegal & Financial & 2.721311 & 1.898518 & 61 & 2.793651 & 1.960569 & 63 \\
\hline Q & Illegal & Financial & 1.196721 & .653699 & 61 & 1.571429 & 1.593477 & 63 \\
\hline R & Legal & Physical & 3.098361 & 1.989178 & 61 & 3.238095 & 2.226775 & 63 \\
\hline S & Legal & Financial & 2.032787 & 1.741333 & 61 & 2.190476 & 1.839154 & 63 \\
\hline T & Legal & & 4.344262 & 2.344392 & 61 & 3.888889 & 2.141081 & 63 \\
\hline U & Illegal & Financial & 1.934426 & 1.504093 & 61 & 2.222222 & 1.878953 & 63 \\
\hline V & Legal & & 1.57377 & 1.189664 & 61 & 2.52381 & 1.891041 & 63 \\
\hline X & Legal & Financial & 2.442623 & 1.793735 & 61 & 2.984127 & 1.987802 & 63 \\
\hline Y & Legal & Physical & 1.47541 & 1.298801 & 61 & 1.52381 & 1.594923 & 63 \\
\hline Z & Legal & & 2.032787 & 1.494068 & 61 & 2.349206 & 1.935731 & 63 \\
\hline
\end{tabular}

Source: Elaborated by the authors.

With these results, we can accept $\mathrm{H}_{0}$ There is a difference in the ethics perception between accounting students and accountants. Taking a further analysis, we can single out the questions with more variability. Scenario $D$, underreport of income tax, scenario $M$, hiring a male employee instead of a female only because of gender, scenario $V$, bribe manager to make a sale, and scenario $X$, cut production costs with risks of injuries, has a significant difference between the perception of students and accountants. Emphasizing the bribery situation with an alarming .95004 difference that accountants find it more acceptable than the students.

In addition, looking at Table 4, there is a difference between accountants and students in the least acceptable situation. Although both the accountants and the students agree with scenario $T$ of donating obsolete computers as being the most acceptable situation, accountants find that scenario $B$, exceeding legal limits of pollution, as the least acceptable case and the students points at scenario $Q$, rolling back car's odometers to increase sales, as the worst case. These results also differ from the study by Antonovz, Stanley and Espejo (2016) applied in the state of Paraná in Brazil, where they also found difference between accountants and students, but the questions with more significant difference is besides $M$, hiring a male employee instead of a female only because of gender, $P$, downloading paid software for free and $U$, announcing being open to bribery.

In order to prove the next hypothesis that the gender can have significant difference in the ethics perception, it was performed a discriminant analysis separating by gender as showing in Table 5. 
Table 5 - Summary of descriptive analysis by gender

\begin{tabular}{|c|c|c|c|c|c|c|c|c|c|c|c|c|}
\hline \multirow{3}{*}{ Variable } & \multicolumn{6}{|c|}{ Accountants } & \multicolumn{6}{|c|}{ Students } \\
\hline & \multicolumn{3}{|c|}{ Men } & \multicolumn{3}{|c|}{ Women } & \multicolumn{3}{|c|}{ Men } & \multicolumn{3}{|c|}{ Women } \\
\hline & Mean & Std. Dev. & Obs. & Mean & Std. Dev. & Obs. & Mean & Std. Dev. & Obs. & Mean & Std. Dev. & Obs. \\
\hline A & 2.647059 & 1.952192 & 34 & 2.344828 & 1.968971 & 29 & 2 & 1.576340 & 34 & 2.111111 & 1.601282 & 27 \\
\hline B & 1.558824 & 1.636537 & 34 & 1.344828 & 1.142549 & 29 & 1.91177 & 1.400598 & 34 & 1.148148 & 0.4560452 & 27 \\
\hline $\mathrm{C}$ & 1.617647 & 1.371014 & 34 & 1.758621 & 1.661651 & 29 & 1.79412 & 1.148897 & 34 & 1.22222 & 0.4236593 & 27 \\
\hline $\mathrm{D}$ & 2.117647 & 1.701420 & 34 & 2.344828 & 1.913782 & 29 & 1.61765 & 1.206415 & 34 & 1.62963 & 1.418237 & 27 \\
\hline $\mathrm{E}$ & 2.000000 & 1.890967 & 34 & 2.206897 & 1.760262 & 29 & 2.73529 & 2.093407 & 34 & 1.851852 & 1.485926 & 27 \\
\hline$F$ & 588 & 1.862473 & 34 & 2.310345 & 1.910562 & 29 & 294118 & 2.214842 & 34 & 2 & 1.208941 & 27 \\
\hline $\mathrm{G}$ & 2323529 & 1.980520 & 34 & 2.586207 & 1.842305 & 29 & 2.5 & 1.862712 & 34 & 2.074074 & 1.591466 & 27 \\
\hline $\mathrm{H}$ & 2.705882 & 2.125308 & 34 & 2.206897 & 1.780436 & 29 & 2.47059 & 1.744868 & 34 & 1.592593 & 1.152231 & 27 \\
\hline I & 2205882 & 1.996655 & 34 & 1.896552 & 1.588909 & 29 & 2.52941 & 1.894734 & 34 & 1.962963 & 1.675192 & 27 \\
\hline $\mathrm{J}$ & 2.882353 & 2.099996 & 34 & 2.344828 & 0.016097 & 29 & 3.08824 & 2.234274 & 34 & 2.185185 & 1.664956 & 27 \\
\hline $\mathrm{K}$ & 2.735294 & 2.206173 & 34 & 2.137931 & 1.726353 & 29 & 2.94118 & 2.228482 & 34 & 2.407407 & 2.170772 & 27 \\
\hline L & 1.970588 & 0.185023 & 34 & 1.586207 & 1.476416 & 29 & 1.61765 & 1.34873 & 34 & 1.259259 & 0.8590063 & 27 \\
\hline M & 2.852941 & 2.090851 & 34 & 1.827586 & 1.605103 & 29 & 2.14706 & 1.844441 & 34 & 1.444444 & 1.120897 & 27 \\
\hline $\mathrm{N}$ & 2.588235 & 1.971273 & 34 & 2.103448 & 1.858279 & 29 & 2.58824 & 1.940285 & 34 & 1.962963 & 1.505924 & 27 \\
\hline 0 & 1.735294 & 1.746144 & 34 & 1.620690 & 1.373572 & 29 & 1.61765 & 1.231277 & 34 & 1.518519 & 1.396985 & 27 \\
\hline$P$ & 3235294 & 2.045821 & 34 & 2.275862 & 0.175044 & 29 & 2.91177 & 2.035557 & 34 & 2.481481 & 1.718013 & 27 \\
\hline Q & 1.705882 & 1.642788 & 34 & 1.413793 & 1.547284 & 29 & 1.17647 & 0.626224 & 34 & 1.22222 & 0.6979824 & 27 \\
\hline $\mathrm{R}$ & 3.588235 & 0.240098 & 34 & 2.827586 & 1.965215 & 29 & 3.61765 & 2.174434 & 34 & 2.444444 & 1.527525 & 27 \\
\hline $\mathrm{s}$ & 2205882 & 1.771481 & 34 & 2.172414 & 1.946957 & 29 & 2.17647 & 1.833536 & 34 & 1.851852 & 1.633865 & 27 \\
\hline $\mathrm{T}$ & 4.411765 & 2.046692 & 34 & 3.275862 & 2.119578 & 29 & 4.73529 & 2.219867 & 34 & 3.851852 & 2.444833 & 27 \\
\hline $\mathrm{U}$ & 2.411765 & 2.031832 & 34 & 2.000000 & 1.690309 & 29 & 235294 & 1.756069 & 34 & 1.407407 & 0.8883545 & 27 \\
\hline $\mathrm{V}$ & 2.735294 & 2.019733 & 34 & 2.275862 & 1.729916 & 29 & 1.79412 & 1.493002 & 34 & 1.296296 & 0.5417078 & 27 \\
\hline $\mathrm{x}$ & 3.382353 & 2.322677 & 34 & 2.517241 & 1.404602 & 29 & 2.94118 & 1.90599 & 34 & 1.814815 & 1.442141 & 27 \\
\hline $\mathrm{Y}$ & 1.558824 & 1.636537 & 34 & 1.482759 & 1.572548 & 29 & 1.79412 & 1.665686 & 34 & 1.074074 & 0.2668803 & 27 \\
\hline Z & 2.794118 & 2.100208 & 34 & 1.827586 & 1.605103 & 29 & 2.52941 & 1.762149 & 34 & 1.407407 & 0.6938887 & 27 \\
\hline
\end{tabular}

Source: Elaborated by the authors.

Analyzing the results presented, specially the highlighted results the hypothesis $\mathrm{H}_{1}$ There is a difference in the ethics perception among men and women is accepted by the greater difference spotted in the least acceptable scenarios $\mathrm{Y}$, noisy factory in residential area, $\mathrm{B}$, exceeding legal environmental limits of pollution and $Q$, rolling back car's odometers to increase sales. The results align with the results found in the studies of Gilligan (1982), Biaggio (1999), Adkins and Radtke (2004), and Emerson, Stanley and Conroy (2007).

\section{CONCLUSIONS}

The present study was motivated by the current corruption scandals in Brazil and the new international law about ethics, NOCLAR, being implemented since July 2017. Previous researches, motivated by similar reasons, by Emerson, Stanley and Conroy (2007) and Antonovz, Stanley and Espejo (2016) were used to compare the results since the questionnaire utilized in this paper was developed by Emerson, Stanley and Conroy (2007).

The findings of this research accepted the Null Hypothesis $\left(\mathrm{H}_{0}\right)$ with the affirmative of a difference between students and accountants' ethics perceptions, since the results indicated 
less tolerance of the students towards questionable scenarios. Most likely due to working with such situations, made the accountants more susceptible to it. These were also the finding of the previous researches.

To achieve the whole scope of the objective, further analysis was conducted in order to prove $\mathrm{H}_{1}$-There is a difference in the ethics perception among men and women. With the results obtained the difference between men and women's perception showed relevancy, accepting $\mathrm{H}_{1}$ and not only the findings proved the hypothesis but there is a greater difference between women and men's ethics perception than between accountants and students.

It is important to highlight the limitations of this research that cannot be controlled. The sample was self-selected by an online survey, and since the number of responses were not as expected it is hard to generalize the results. However, the sample was almost even with students and accountants, so the comparison between them is possible.

This study is only one step towards the understanding of accounting ethical behavior across the world. As in the original study, it is suggested that future research expand the number of regions or even countries at the same time, for a deeper understanding of the global population's perception of ethics.

\section{REFERENCES}

ABDOLMOHAMMADI, M. J.; READ, W. J.; SCARBROUGH, D. P. Does selection-socialization help to explain accountants 'weak ethical reasoning? Journal of Business Ethics, v. 42, n. 1, p. 71-81, Jan. 2003.

ADKINS, Nell; RADTKE, Robin R. Students' and Faculty Members Perceptions of the Importance of Business Ethics and Accounting Ethics Education: Is There an Expectations Gap? Journal of Business Ethics, v. 51, n. 3, p. 279-300, May 2004.

ALVES, F. J. S. Adesão do contabilista ao código de ética da sua profissão: um estudo empírico sobre suas percepções. Advisor: Lázaro Plácido Lisboa. 2005. 273 f. Thesis (Doctorate in Accounting) - Universidade de São Paulo, São Paulo, SP, 2005.

ALVES, F. J. S.; LISBOA, N. P.; WEFFORT, E. F. J.; ANTUNES, M. T. P. Um estudo empírico sobre a importância do código de ética profissional para o contabilista. Revista de Contabilidade e Finanças, v. 18, n. special, 2007.

ANTONOVZ, T. Atitudes éticas dos contadores: evidências recentes de uma pesquisa com alunos e profissionais. Advisor: Márcia Maria dos Santos Bortolocci Espejo. 2010. Dissertation (Master in Accounting) - Universidade Federal do Paraná (UFPR), Curitiba, PR, 2010.

ANTONOVZ, T.; STANLEY, C.; ESPEJO, M. M. S. B. (2016). Ethical attitudes of accountants in Brazil: recent evidence from students' and accounting professionals' survey. International Research Journal of Applied Finance, v. 7, p. 188-201, Aug. 2016.

BIAGGIO, Â. M. B. Universalismo versus relativismo no julgamento moral. Psicologia, Reflexão e Crítica, Porto Alegre, v. 12, n. 1, 1999.

CARRANÇA, T. Contador terá que reportar irregularidade a partir do ano que vem. Available in: http:// www.valor.com.br/empresas/4768369/contador-tera-que-reportar-irregularidade-partir-do-ano-que-vem. Accessed in: 7 July 2016.

CONSELHO FEDERAL DE CONTABILIDADE (CFC). Aplicação da Noclar no Brasil é tema na Ifac. BRASílIA: CFC, 2018. Available in: http://cfc.org.br/noticias/aplicacao-da-noclar-no-brasil-e-tema-de-reuniao-naifac/. Accessed in: 13 Mar. 2018. 
EMERSON, T.; STANLEY, C. W.; CONROY, S. J. Ethical attitudes of accountants: recent evidence from a practitioners' survey. Journal of Business Ethics, v. 71, p. 73-87, 2007.

GILLES, P. W. A nova Ética. 2. ed. Rio de Janeiro: Rosa dos Tempos, 1994.

GILLIGAN, C. In a different voice. Cambridge, Mass: Harvard University Press, 1982.

LISBOA, P. L. Ética geral e profissional em contabilidade. São Paulo: Saraiva, 1996.

LOE, T. W.; FERRELL, L.; MANSFIELD, P. A review of empirical studies assessing ethical decision making in business. Journal of Business Ethics, v. 25, p. 185-204, 2000.

SÁ, A. L. Ética Profissional. 4. ed. São Paulo: Atlas, 2001.

SANTOS, M. F. dos. Sociologia fundamental e ética fundamental. 2. ed. São Paulo: Logos, 1959.

SARBANES-OXLEY ACT OF. Senate and House of Representatives of the United States of América. Public Law 107-204, approved July 30, 2002, 116 Stat. 745. Washington, 2002.

SROUR, R. H. Ética empresarial sem moralismo. Revista de Administração, São Paulo, v. 29, n. 3, p. 3-22, July/Sept. 1994.

\section{About the authors:}

Jessica de Morais Lima: Graduated in Accounting at the niversidade Católica Dom Bosco (UCDB), MBA in Accounting in IFRS at the Instituto Nacional de Estudos e Pesquisas Tributárias (INPET) and Master of Science in Accounting, Accounting Finance and Controller by the Universidade de São Paulo of Economics, Business and Accounting in Ribeirão Preto (FEA-RP/USP). Accountant at LM Contabilidade Ltda. E-mail: jesslima24@gmail.com, Orcid: http://orcid.org/0000-0002-6318-5095

Marcia Maria dos Santos Bortolocci Espejo: PhD in Controller and Accounting by the Universidade de São Paulo (FEA/USP). Master of Science in Business by the Universidade Estadual de Londrina (UEL). General Chief of Post Graduate School (CPG) of the Research and Post Graduate Pro-Rectory (PROPP), in the Universidade Federal de Mato Grosso do Sul (UFMS), and Associated Professor at the Escola de Administração e Negócios (ESAN/UFMS). E-mail: marcia.bortolocci@ufms.br, Orcid: http://orcid.org/0000-0002-9081-781X

Marcelo Botelho da Costa Moraes: PhD in Economy, Organization and Management. Master of Science in Production Engineer and Professor in the School of Economics, Business and Accounting in Ribeirão Preto (FEA-RP). E-mail: marcelo.moraes@usp.br, Orcid: http://orcid.org/0000-0003-0761-0883

Emanoel Marcos Lima: PhD and Master of Science in Accounting by the Universidade de São Paulo (FEA/USP). Post Graduated in Forensic and Financial Accounting Investigation by the Universidade Católica Dom Bosco (INPG/UCDB). Associated Professor at the Escola de Administração e Negócios (ESAN/UFMS). E-mail: emanoel.lima@ufms.br, Orcid: http://orcid.org/0000-0002-2573-5850 
